\title{
Immunotoxiciteit: een zintuig uit balans
}

Citation for published version (APA):

van Loveren, H. (2003). Immunotoxiciteit: een zintuig uit balans. Universiteit Maastricht. https://doi.org/10.26481/spe.20030626hl

Document status and date:

Published: 26/06/2003

DOI:

10.26481/spe.20030626hl

Document Version:

Publisher's PDF, also known as Version of record

\section{Please check the document version of this publication:}

- A submitted manuscript is the version of the article upon submission and before peer-review. There can be important differences between the submitted version and the official published version of record.

People interested in the research are advised to contact the author for the final version of the publication, or visit the DOI to the publisher's website.

- The final author version and the galley proof are versions of the publication after peer review.

- The final published version features the final layout of the paper including the volume, issue and page numbers.

Link to publication

\footnotetext{
General rights rights.

- You may freely distribute the URL identifying the publication in the public portal. please follow below link for the End User Agreement:

www.umlib.nl/taverne-license

Take down policy

If you believe that this document breaches copyright please contact us at:

repository@maastrichtuniversity.nl

providing details and we will investigate your claim.
}

Copyright and moral rights for the publications made accessible in the public portal are retained by the authors and/or other copyright owners and it is a condition of accessing publications that users recognise and abide by the legal requirements associated with these

- Users may download and print one copy of any publication from the public portal for the purpose of private study or research.

- You may not further distribute the material or use it for any profit-making activity or commercial gain

If the publication is distributed under the terms of Article $25 \mathrm{fa}$ of the Dutch Copyright Act, indicated by the "Taverne" license above, 


\section{IMMUNOTOXICITEIT}

Een zintuig uit balans 
Illustratic omslagt J. Hoekman

Druke Datawyse / Universitaire Pers Maastricht

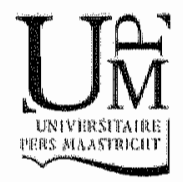

$158 \mathrm{~N} 9052783853$

OHenk wan Loweren, Mansericht, 2003 


\section{IMMUNOTOXICITEIT Een zintuig uit balans}

Rede

Uitgesproken bij de aanvaarding van het ambt van bijzonder hoogleraar Immunotoxicologie aan de Faculteic der Gezondheidswerenschappen van de Universiteit Maastricht op donderdag 26 juni 2003.

Henk van Loveren 

Mijnheer de Rector Magnificus

Zeer geachte dames en heren

\section{HET IMMUUNSYSTEEM}

\section{Functie}

Stelt $U$ zich voor: een voetbalveld, maar dan zonder een sprietje onkruid. Zonder kevertjes, slakjes, wormpjes. Geen schimmels, geen bacterien. Alleen de door u gewenste grassprieten. Hoe goed moet u wel kijken om in dat hele veld al die ongerechtigheden om te beginnen mar eens te zien, latat staan te verwijderen. En als het u al lukt, wat een moette moet u dan doen orn her ook zo te houden. Vergelijkt u dan eens een voetbalveld met de longen. Als u alle longblaasjes waaruit de long is opgebouwd zou uitspreiden heeft u her oppervlak van een voetbalveld. En die longen zijn wel steriel. Er groeien als het goed is geen bacterien in of virussen, of schimmels, of parasieten.

Om dat zo te houden wordt er minutieus gekeken of die ongerechtigheden soms toch toegang willen krijgen. Dat gebeurt door een systeem dat heel goed een zintuig genoemd kan worden, omdat het voorturend kijkt of het licham wordt bedreigd. Dat systeem is het afweersysteem, of immuunsysteem. Niet alleen de longen maar alle oppervlakten die met de butenwereld in contact staan worden door dit systeem voortdurend in de gaten gehouden. Denkt u aan de huid. Denk aan openingen in her lichaam zoals ogen, neus, urogenitaalopeningen. Hoe dacht u dat u een blaasontsteking opliep. Denk ook aan het maag-darm kanaal. U neemt minimaal drie maal daags voeding tot $\mathrm{u}$, en die voeding is zeker niet steriel en toch wordt u meestal niet ziek. Het maag darm kanal is overigens zelf ook helemaal niet steriel. Er zitten tal van microben in, maar die zijn juist heel belangrijk want ze helpen bij de afbratk van het voedsel. Die zogenaamde microflora in uw mag-darmkanaal is niet schadelijk voor $u$, maar her kan voorkomen dat $U$ bij het innemen van voeding toch wel degelijk schadelijke broeders mee nar binnen krijgt. $U$ heef dan iets verkeerd gegeten en het immun nsysteem ziet dat feilloos.

Behalve dat het immuunsysteem ziet wat er naar binnen probeert te komen, zorgt het or ook voor dat die binnendringers worden opgeruimd. 
Hot doet het immunsystem dat? Een eerste reactie op binnendringers wordt gegeven door ontstekingscellen. De snelste zijn de zogenaamde neutrofiele granulocyten. Dit zijn witte bloedlichampjes, die onder de microscoop gekarakeriseerd worden door een gelobde kern en specifeke keuregenschappen. Ze gaan naar de plek des onheils toe en proberen de microben op re nemen en re doden.

Ook macrofagen kunnen dit, ook dat zijn witre bloedlichampjes die in de bloedcinculatie voortkomen, mar ook in tal van weefsels als vaste cellen aanwezig zijn wn die in staat zijn allerlei ongerechtigheden op te nemen en af te breken. Vandaar hun naam: macrolagen betekent "grote eters'. Bij deze functies van ontstekingscellen komen ontstekingsmediatoren wrij, en worden zuurstof radicalen, hele gifrige verschijningsvormen van zururstof gevormd, die een tol spelen bij het opruimen wan de indringers, maar daarbij ook kunnen leiden tor schade an de eigen weefsels warin de infectic plaatsvindt. Die neutrofielen en macrofagen kunnen worden gezion als de grove opruimers: is er iers aan de hand dan ruimen zij de bulk wan de rommel op. Maar microben zijn slimmerds, ze kumnen zich vermeniguldigen, soms zelfs binnen in die ontstekingscellen zelf, en die cerste reactie is daarom toch valk niet voldoende om een infectic te stoppen. Die ontstekingscellen worden dan geholpen door het zogenaamde specifieke immunsysteem.

Het specifeke immunsystem wordt gevormd door lymfocyten. Bepaalde lymfocyten, B lymfocyten, maken antilichamen. Dat zijn eiwitten die een uiteinde hebben, warmee ze hele specificke structuurjes op de menbraan wan een pathogeen kunnew herkennen. Die structuurtjes worden antigenen genoemd, en als een antilichaam zo'n anrigeen op een microbe ontdekt, kan hij deze neutraliseren. Een bepaald antilicham is in stat is om alleen mast eén specifiek antigen op een bepaald pathogeen te herkennen. Masr de verscheidenheid aan antigenen is bijzonder groot Was u onder de indruk van het verhal over het voetbalveld, zeker zo indrukwekkend is het vermogen van het immunsysteem om heel veel verschillende antigenen te herkennen. Waar het oog, toch een zeer scherp zinuig, donker en licht, alsmede de drie primaire kleuren rood, geel, en blaw kan herkonnen, kan her immunnsystem honderdduizenden verschillende antigenen onderscheiden. Antilichamen worden geproduceerd doon het aflezen van een stukje genoom dat zich bevind in de celkern wan 
de lymfocyt. Echer, indien men berekent hoeveel DNA nodig zou zin om te coderen voor al die verschillende antilichamen met al die verschillende specificiteiten, dan blykt dat her hele genoom in de B lymfotyt bij lange na niet groot genoeg is. Daartoe beschikt het immuunsysteem dan over een zeer ingenieus mechanisme, warbij in voorloper lymfocyten voorloper DNA in stukken wordt geknipt, terwijl verschillende delen dan weer opnieuw in ekaar worden gezet tot DNA dat voor de producrie wan antilichamen verantwoordelijk is. Die recombinatie is een at random proces: in elke lymfocyt komt een andere DNA configuratie tereche. Zo onstaat een enorme diwersiteit aan werschillende specificiteiten: alles wat herkend kan worden wordt ook herkend. Daarbij is dan ook tegelijkertijd sprake van een mogelijk probleen: antilichamen die antigenen op tiektewerwelkende microben herkennen zijn zeer gewenst, mar zodra ook lichaamseigen eiwitten worden herkend is Leiden in last. En hetzelfde geldt voor Maastricht en Bilthoven. Er moet dus een systeem bestan om die ongewenste specificiteiten niet tot on wwikkeling te laten komen. Daarover straks meer.

Behalve B cellen, bestaat er een andere groep van lymfocyten, de zogenaamde $T$ lymfocyten. Deze cellen maken geen antillichamen, mar hebben op hun membraan antigeen-herkennende receptoren. Ook voor T cellen geldt dat er een enorme diversiteit aan specificiteiten bestat; die net als bij die $B$ cellen door een proces van genherrangschikking tor stand komt. Die $T$ cellen hebben verschillende functies. Een heel belangrijke is dat cellen warop antigenen tot expressie komen, bijvoorbeeld cellen die zijn geïfecteerd met een virus, door $T$ cellen kunnen worden herkend en geèlimineerd, doordat er letterlijk een gaatje in wordt geprikt. Ook kunnen $T$ lymfocyten allerlei producten afgeven, zogenaamde interleukinen, warmee ze andere cellen, zoals bijyoorbeeld de eerder genomite macrofagen, werder in hun activiteit stimuleren, watbij de afweerfunctie wordt ondersteund. Verder kunnen $\mathbb{T}$ cellen $B$ cellen stimulerer in hun activiteit antilichamen te produceren. Zonder deze hulp worden de meeste antilichamen niet eens gevormd.

Ook voor $T$ cellen gelde dat bij de on rwikkeling van de diversiteir in specificiteiten mogelijk $T$ cellen zouden kunnen worden aangelegd, die lichaamseigen structuren zouden kunnen herkennen. Als eerder angegeven beschikt het immunusysteem over een mechanisme waamee die on- 
gewente specificiteiten worden uitgeschakeld. Dar gebeurn in de thymus, vandaar ook de nam T cellen. Voonlopercellen, afkomsng uit het beenmerg, bereiken de thymus via de cortex. In de cortex interageren ze met epithehale cellen, tijdens welke interactie die vootlopercellen differentieren. Er worden verschillende belangrijke receptoren op die cellen gezet en ook het proces wan genherrangschilking vind dan plaats. Cellen die een ongewenste specificiteit tot expressie brengen worden door die interactie herkend, ze redden het niet en gaan dood Cellen die een gewenste specificiteiten tot expressie brengen, en die we dus voor afweer nodig zouden kumuen heblaen gatan door, vertaten witeindelijk de thymus, en komen in de circulatie tereche.

Van de verschillende lymfocyren mer hun eigen specificiteiten zijn doorgans slechts weinig exemplaren aanwezig. Pas indien nodig, war blijkt als zo'n cel herkent dat er een antigeen in de buurt is en er dus acte is vereist, word hun antal amzienlijk verhoogd doordat ze gaan delen. Is er een infecte geweest dan neemt hun aantal doorgaans ook weer af, maar vooral cellen mer een hoge affiniret voor het betreffende antigeen bliven over, waardoor bij een nieuwe infectie heel snel gereageend kan worden. Van dit mochanisme wordt gebruik gemaakt bij het vaccineren.

\section{Balans}

Er is sprake van een balans in immumresponser, die is gebaseerd op verschillende $T$ lymfocyten. Daarbij is enerzijds Interferon- $\gamma$ van belang, dat met name wordt geproduceerd door zogenaamde Thl lym focyren en IL-4 en -10, die worden geproducerd door Th-2 lymfocyten. Th1 lymfocyten stimuleren met name cellulaire immuunesponsen (zoals cytotoxische $T$ cellen en macrofagen), terwijl Th2 lymfocyten met name humorale immunuresonsen van het type $\mathrm{ggE}$ stimuleren. Die ThI en Th2 lymPocyen beinvoeden elkaars acrviteit, hetgeen resulteert in een balans. Verstoring wh de balans kan leiden tot ongewenste reacties. Bijvoorbeeld cen togenomen Th2 activiteit gepard gand mer en afgenomen Th acriviteic kan leiden tot een roegenomen IgE productie, gepard gaand mer respitaroite allergie, ten koste van weerstand die gebaseend is op cellulaire immuniteit.

Ontrelking is een belangrijke component in afweer tegen infecrieuze agenria en tumoren. Ontstekingscellen die naar een infectie of tumor- 
haard worden aangetrokken en daar worden gestimulleerd brengen schade toe an die pathogenen of tumorcellen. Het specifieke immuunsysteem is van belang bij het rekruteren en stimuleren van nog meer ontstekingscellen. Tevens reguleert het specifieke immuunsysteem de ontstekingstespons zo, dat zodra het infectieuze agens is verdwenen de ontsteking stopt.

De keerzijde van ontsteking is dat ook schade aan de omringende weefsels zelf wordt toebracht. Dit is vooral een probleem wanneer het ontstekingsproces ontspoort en een chronisch karakter krijgt. Een klassiek voorbeeld is tuberculose, waarbij de tuberkelbacteriën in staat zijn zich in de ontstekingscellen te handhaven, en als gevolg van een doorgaande en "gefrustreerde" ontstekingsrespons granuloomvorming in de longen optreedt. Ook kan het zijn dat het schadelijke agens reeds is verdwenen, maar de ontsteking door gaat. Bij atherosclerose treedt plaquevorming op in bloedvaten. Hieraan ligt een ontstekingsproces ten grondslag geinitieerd door oxidatieve schade, depositie wan geoxideerde lipiden, en wellicht ook als gevolg van infecrieuze agentia (Chlamydia). Tijdens dit proces treden immunnresponsen op, wellicht gedeeltelijk gericht tegen de infectie, maar gaandeweg ook tegen andere componenten in de bloedvaten, en als zodanig is atherosclerose dan ook deels op te vatten als een auto-immuunziekte. Indien atherosclerose als een auro-immusunziekte wordt gezien lijdt uiteindelijk iedereen in min of meerdere mate aan de nadelige gevolgen van auroimmuniteit, voor sommigen met een fatale afloop. Bij allergisch astma is sprake van een respons op een allergeen (bv huisstofmijt) waarbij een onsteking optreedt gekenmerkt door eosinofiele granulocyten. Deze laatste cellen zijn zeer potente ontsrekingscellen, terwijl de allergenen zelf eigenlijk niet zo schadelijk zijn. Omdat huisstofmijt overal voorkomt, krijgt het ontstekingsproces een chronisch karakter.

Behoudens schade toegebracht door pathogenen kumnen ook andere agentia, zoals chemische stoffen of straling, aanleiding geven tor schade, zoals oxidatieve schade leidend tot veranderingen in eiwitten of DNA. Ook dic weefselschade wordt doorgaans opgeruimd waarbij ontstekingscellen en daarmee her immuunsysteem betrolkken zijn. 


\section{IMMUNOTOXICITEIT}

\section{Inmutusuppressie}

Bif immunoroxiciteit, en dat is het gebied warop de leerstoel zich begeft, is sprake win benvloeding van het immunsysteem doot chemische of fysische factoren. Een vorm van immunotoxiciten is die waarbij verbindingen verschillende componenten van het immunusysteem beschadigen. Het "zintuig immuunsysteem" ziet het allemaal niet meer zo scherp. Als voorbeeld kan dienen een verbinding waar erg veel aan is onderzocht, namelik triburyltnoxide (1), heel bekend cloor het gebruik als antifowling in scheepsverwen. Deze stof belemmert celdeling van lymfocyten wardoor ze in hun functe worden belemmerd.

Een ander voorbeld wordt gevormd door en groep van verbindingen warvan dioxine en ook PCB's deel uitmaken, u weet wel, een verontreinigend bestanddeel dat soms na gesjoemel in verhoogde concentracies in de voeding is angetroffen. Deze stoffen hechten an de zogenaamde Aryl hydrocabon receptor, die op veel verschillende cellen aanwezig is. Een hoge dichtheid van die receproren zit op epitheelcellen in de thymus, en als gevolg daarvan wordt de differentiatie van rijpe $T$ cellen verstoord. Na blootstelling aan dergelike verbindingen vindt dan ook een verminderde immuunrespons plaats (2).

Door Rik de Swart en Peter Ross in her RIVM $(3,4)$ is aannemelijk gemaakt dat in de via de voeding an $\mathrm{PCB}^{*} \mathrm{~s}$ blootgestelde zeehonden populatie in de Waddenzee een verminderde weerstand tegen het zeehondenvirus mede ten grondslag lag aan de epidemie in de 80 er jaren, die een belangrijk deel wan de toenmalige populatie heeft uitgeroeid. Ook in de mens werden effecten van PCB's gevonden: verhoogde achtergrondblootstelling in kleine kinderen was geassocieerd met een toegenomen incidentie whith midenoorinfecties zoals aangetoond door Nienke WeisgalsKuperus uir Rotrerdam (5).

Nog een heel ander voorbexld is nier een chemische verbinding maar straling gewoon: ultraviolete straling in zonlicht. Bestraling van de huid leidr rot DNA schade onder andere in cellen in de huid die doorgaans antigeen kunnen presenteren aan lymfocyten, en deze schade leidt tot verminderde immuntesponsen. Ook deze zogenaamde "directe" toxiciteit voor het immuunsysteem kan leiden tot werminderde weerstand tegen 
infecries en tumoren, zoals gevonden door onder andere Wim Goetrsch en Johan Garssen in her RIVM (6). Bekend is de koorthip, een vinsinfecrie die wordt gestimuleerd door ulraviolette straling. In een studie uitgevoerd door Fabian Termorshuizen en Alet Wijga (7) bleek dat bij érnjarige kinderen, warbij zonverbranding had platsgevonden een toegenomen incidentie an middenoorinfectie te zien was. $1 k$ heb zelf een kleintje wan nu 2 jaar, en ik vind het onbegrijpelijk dat ouders zo'n kleintje zo lang in de zon laten dat zonnebrand optreedt, maar het komt kennelijk voor.

Ik heb aangegeven dar het immunsysteem een intensief regelmechanisme kent, waarbij verschillende componenten van het immunnsysteem elkaar in evenwicht houden. Soms leidt interactie tussen exogene factoren en her immunsysteem tot een afname in de funcrie van verschillende onderdelen. Vaak is het echter zo dat door directe toxiciteit balansen worden ontregeld waardoor andere onderdelen juist excessief gatn functioneren. Het zintuig wit balans. In de literatuur is beschreven dat deeltjesvormige luchtverontreiniging kan leiden tot een verminderde weerstand tegen respiratoire infecties, wellicht door een afname in Thl-athankelijke immuunresponsen, terwijl respiratoire allergie juist kan worden gescimuleerd, zoals onder andere gevonden door Peter Steerenberg in her RIVM. en Maake van Zijverden, samen met Raymond Pleters van IRAS in Urrecht $(8,9)$. Zij vonden meer IgE indien dieren aan een allergeen in aanwezigheid van dieseldeeltjes werden blootgesteld, in vergelijking tot dieren die alleen allergeen zagen. De toegenomen mortaliteit na een periode met verhoogde luchtverontreiniging zou voor een deel terug te voeren kunnen zijn op de interactie met respiratoire immunologische processen. Ik kan me voorstellen dar bij de besluirvorming betreffende de ondertunneling wan de $\mathrm{A} 2$ rekening wordr gehouden mer deze informatic.

\section{Sensubilisatie}

Naast directe toxjciteit voor het immunsysteem kan ook sprake zijn van indirecte immunotoxiciteit. Sommige verbindingen kunnen specifiek worden herkend door het immuunsysteem, en er treedt dan een specifieke immunrespons tegen die stof op, die in feite een normale respons is. Echter, omdar mmunresponsen gepard gaan met schade aan het eigen weefsel, en omdar bij hernieuwd contact mer de verbinding de responsen 
plates kunen vinden bij lagere concentraties, kan de schadelijkheid van de immunnespons de eventuele directe schadelijkheid van de verbinding verre overreffen. Ook dan dus geen gebalanceerde respons. In dat geval is sprake wan chenisch-geinduceerde overgevoeligheid of allergie. Daarbij kan her gaan on verbindingen met en laag molecuulgewich die doorgans, mat niet aldjd, huidsensibilisatie induceren. Verbindingen met en hoger molecuul gewiche, proteinen, induceren doorgaans (maar ook néer uitsluitend) humorale, IgE a Phankelijke immunnesponsen.

Naast huidallergie en tespiratoire allergie als schadelijke, en derhalve immunotoxische, effecter van verbindingen is een specificke vorm van alergie nog voedselallergie. Voedselallergie onderscheidt zich van woedselintolerantie, omdat het bij voedselallergie gaat om immunologisch specifrekc responsen (vaak IgE responsen) tegen specifieke allergenen, meestal eiwitren. Voedselallergio kan worden veroorzaalkt door proteinen die kunnen vookomen in de voeding. Vrijwel ieder lichaamsvreemd eiwit kan immunresponsen opwekken. Doorgaans ontwikkelt deze immuunrespons zich niet rot een allergische respons. Echter, onder bepalde omstandigheden ontstaat toch voedselallergie. De omstandigheden kunnen te maken hebben met her eiwit zelf; sommige eiwitten zijn meer in stat tor her induceren van voedselallergie dan andere.

De prevalentie van woedselallergie is 2 tot 3 procent, bij kinderen jets hoger, ongeveer 6 procent. Doorgaans zijn de verschijnselen niet emstig. mar in sommige gevallen kunnen de reacties zo hevig zijn dat men in een shock rakt en overlijd.

De beste bescherming tegen voedselallergie is voedsel warin de voor jou allergene componenten zitten te mijden, mat dat is heel erg lastig: zoek maar eens uit in welk voedsel pinda's worden gebruikt, wat je dan dus niet moet eten. $U$ zult versteld staan. Toch is her probleem van voedselallergie nier zo heel groot; in die zin dat we de belangrijkste woedselalJergenen wel kennen: pinda" $s_{\text {: }} \mathrm{i}$, mel $k$, schaaldieren, amandelen, paranoren. Voor her voorspellen of bepalde voedingsbestanddelen allergeen zullen zijn bestan er eigenlijk geen goede methoden. Dat is wel een problecm, mer name voor nieuwe voedingsmiddelen warbij door middel van gentechnologieèn, nieuwe eiwitcen in voedingsgewassen worden gebracht. De Stallink affaire, warbij een eiwit in voedingsmais werd ingebracht dar ahkomstig was van een schimmel en dat mais een werhoogde weerstand 
gaf, waardoor bestrijdingsmiddelen minder nodig waren, kan dienen als een voorbeeld. Hoewel niet aangetoond bestond er angst voor indwerie van voedselallergie, en toen deze transgene mais in de menselijke voedselketen terecht kwam is het van de markt gehaald.

Verwacht kan worden dat behalve de aard van de eiwitten zelf ook condities in de voeding een rol spelen bij the ontwikkelen wan woedselallergie. Daarbij valt te denken aan de marrix waarin de eiwitten zich bevinden. Pinda's en pindakaas zijn niet herzelfde. Ook is het denkbar dat immunomodulerende componenten in de woeding, of immunotoxische contaminanten, de ontwikkeling wan immumresponsen tegen potentied allergene eiwitten kunnen beinvloeden. Tenslotte moet worden genoemd dar individuen heel verschillend op voedselallergenen kunnen reageren: ikzelf kan zonder bezwaar de pinda te lijf maat dat geldt nier voor iedereen. Om meer inzicht in risicofactoten voor voedselallergie te verterigen wordt in opdracht van de Keuringsdienst van Waren van de Voedsel en Waren Autoriteit een AIO project opgestart.

Niet door iedereen wordt overigens chemisch-geinduceerde allergie tor her gebied van de toxicologie gerekend. Dan wordt doorgans toxiciteit als een beperkr begrip opgevat, als een niet specifiek insult uiteindelijk leidend tor celdood, terwijl de schadelijke gevolgen van immumnesponsen op een verbinding rot her gebied van de allergologie of immunologie worden gerekend. Soms heb ik daabij her gevoel dat andere dan wetenschappelijke argumenten, misschien wel belangen, bepalend zijn voor de positie die wordt betrokken. In mijn beleving is ieder schadelijk effect van een lichaamsvreemde verbinding te beschouwen als toxiciteit, en reken ik chemisch-geinduceerde allergie dan ook tot aandachtspunt woor mijn leerstoel. Ik heb er geen enkel bezwat tegen dat anderen genoemde fenomenen ook tot de allergologie of immunologie wensen te rekenen; voor mij ondersteunt dat alleen maar de noodzaak om vanuit de verschillencle dis ciplines, en dan liefst gezamenlijk, tegen deze materie an te kijken.

\section{Autoimmuniteit}

Een derde vorm van immunotoxiciteit is chemisch-geinduceerde autoimmuniteit. Indien lichaamseigen componenten zo door verbindingen worden veranderd dat het immunsysteem ze ziet als lichaamsvreemd kan auroimmuniteit ontstan. Dit fenomeen rreed onder andere op na be- 
handelng mer sommige gencesmiddelen. Ontwikleling van immunresponsen tegen exogene agentia kan ook tot gevolg hebben dat lichaamseigen componenten herkend gaan worden iets dergelijks kan plaatswinden indien dat lichaamsvreende product en de lichaamseigen componert en antigene overenkomst vertonen. Dit is vooral bekend van bacteriele producten. Mogelijkerwijs kan ook een effect op het niveau van selectie wan specificiteren wan lymfocyten, zoals dit in de thymus optreedt, tot autoimmunter leiden. In experimentele modellen met het gereesmiddel cyclospotine, dat een effect op de architectur van de thymus kan hebben, is dit wel angeroond.

Behalve nadelige effecten kunnen verbindingen ook posiveve effecten op the immumsystem hobben. Voobeelden zijn onder andere visolieveruten en vitaminen. Bij ontstekingsreacties is radicalvorming door ontstekngscellen van belang. Zij spelen een rol bij het termineren van pathogenen, mar leveren tevens schade aan de omringende weefsels op. Vitamine $\mathbb{E}$ vangt radicalen weg, hetgeen derhalve ontstekingsremmmend werk. Dait is een positief effect. Tegelijkertijd is her voorstelbaar dat ook de gewenste werking van de ontsteking teniet gedaan kan worden. Eén en ander impliceert dat er een kritische dosis voor Vitamine $E$ moet bestaan: er is immers een zeker niveau wan radicalen nodig om de parhogenen te doden, en teveel Vitamine E zou her gewenste ontsrakingseffect kunnen belemmeren. Er is met andere woorden sprake van een fijne balans.

Van toevoeging van probiotica (bepaalde bacterienn zoals de Lactobaccillus) aan voedingsproducten (u kent welliche allemaal de bekertjes van Yacult) wordt geclaind dat deze gezondheid zouden bevorderen door stimulatie van het immunsysteem ten aanzien van weerstand tegen infecties en onderdrukking wan allergie. Ook voor bewust nagestreefde beinvocding van hat immunusysteem geldt dat men zich moet realiseren dat het immunsysteem balansen kent, en dat onderdrukking van allergie an stimulate van weerstand wel cens negatieve effecten zou kunnen hebber, zoals bevordering van autoimmuniteit. Studies met hexachloorbenzeen in de rat ondersteunen dat: stimulate van immunnesponsen kunnen eenvoudig worden angetoond in her proefdiermodel, maar even eenvoudig Kan worden aangetoond dar HCB dosis-gerelateerd paralyse als gevolg van alleggische encephalomyelitis, een model voor de auto-immuunzielste multipele sclerose in de mens, in ernstige mate kan bevorderen (10). 
Mijn persoonlipke voorkeur voor een voedingspakker is dan ooks gebruik een gevarieerd menu. De welbekende schijf wan vijf of moderner: de voedingspyramide. Voldoende groenten en fruit, wardoor voldoende vitaminen. Voldoende vis. Nier al te veel rood vlees, werzadigd ver. Ook niet al te vee bestrijdingsmiddelen. En hoedt $U$ voor al te veel pillen en poeiers: uw zoveelste zintuig, het immunsystem, kan uit balans.

\section{Vaststellen van immunotoxiciteit: immunnsuppressie}

Het onderzok nar histologische veranderingen in de thymus, milt of lymfklier als gevolg van blootstelling aan toxische werbindingen, zoals bijwoorbeeld na blootstelling aan PCB's, die een duidelijke afname van thymocyten in de thymus induceren, of hexachloorbenzeen, dat juist een duidelijk toename van her antal lymfocyten in de marginale zone in de milt induceert, is een startpunt woor de ontwikkeling wan de immunotoxi cologie geweest. Sjef Vos, nog altijd actief, heeft al in de jaren zeventig daarmee de basis voor de immunotoxicologie gelegd. Mede op grond van dat wroege werk zijn richdijnen woor weiligheidsonderzoek an milieuverontreinigende verbindingen en geneesmiddelen zo aangepast dat ook het immunsysteem als potentieel doelwitorgan voor toxiciteit wordt geêwalueerd.

Histopathologie is een semi-kwantitatieve analysevorm, en is als screening voor immunotoxiciteit zeer waardevol. Echter, in de internationale immunotoxicologische gemeenschap bestaat consensus dat de meest adequare manier om het functioneren van het immuunsysteem na blootstelling aan toxische verbindingen te onderzoeken is het testen van de functie van her immutusysteem, bijvoorbeeld het immuniseren van dieren met cen $T$-cel afhankelijk antigeen, om vervolgens naar de antilichaamirespons te kijken. De rationale is dat bij deze respons de belangrijkste aspecten van het immunnsysteem aan bod komen; en schade an het immunsysteem derhalve goed kan worden opgepilkt. Her is moeilifk te verteren dat er, met name in sommige kringen wan de chemische en famacoutische inclustrie, vel weerstand bestat tegen het opnemen wan een dergelijke funcrionele parameter in het veiligheidsonderzok. De veel gehoorde argumentarie daabij is dat gegevens die met dergelijk onderzoek worden gegenereerd niet alrijd goed te interpreteren zouden zijin. Bijvoorbeeld: wanneer is cen afname in een antilichamrespons een nadelig effect? En 
hoe kan en effect in het proefdier worden vertald naar mogelike effecten in de mens? En ik kan begripen dat, war grote franciele belangen op her spel stan, angst bestaat dar de toelaring van bepaalde verbindingen op de mark wordt belemmerd door bepaalde bevindingen warvan de relevantic voor de meris niet enduidig wast stat. Tegelijkertijd ben wh ook altid verbaasd over her gemak warmee de conclusie dan getrokken word om functionele tesren dan mar niet op te nemen. Sinds wanneet weten we meer als we minder weten? Mijn inzet is dat meer weten meer weren is, en dat het de uiddaging is de bevindingen juist wh gebalanceerd te interpreteren. Zoals wee letters die ontbreken in de titel van de uitnodiging woor een oratie die untmodiging niet uit balans brengen, zo is evenmin ieder marginal effecte op her immunsysteem een groot problem; niet ieder effecrje hoeft her op de markt brengen van een verbinding te belemmeren. Maar als er een effect worde gevonden is her wel zaak alett te zijn bij het gebruik van her betreffende product, juist op dit gebied wan immunotowiciteit.

Belangrijk hulpmiddelen bij het vaststellen wan de relevantie van immunotoxiciteit zijn ziekremodellen in het proefdier. In dat type onderzoek worden dieren na blootstelling an de te onderzoken verbinding geinfecteerd met en infectieus agens, en wordt vervolgens het verloop van de infectie in kaare gebracht.

Als woorbeeld kan dienen een experiment uitgevoerd mer de al cerder genoende verbinding TBTO, en de weerstand tegen de infecrie mer een parasier Trichinella spiralis (1). Uit dat experiment blijk dat TBTO een vermindering van weerstand oplevert, blikkend uir een roegenomen antal larven na infecrie. Een klinisch heel relewant effect derhalve, althans voor de rat die hier als proefdier is gebruikt. Relevantie wan in proefdieronderzodk gevonden immunotoxiciteit kan wellich het allerbest worden vastgesteld in de mens zelf, mat blootstelling wan de mens an de betreffende stof is en ding, het opzetelijk infecteren is een ander. Op grond van het idee dat het functioneren van het immunsysteem adequar kan worden vastgesteld door middel van sensibilisatio met een T-cel aflankelik antigeen en analyse van de ancilichaamrespons is voorgesteld immunotoxiciteitonderzok in de mens uit te voeren met behulp van vaccinacie. Zo heeft de al eerder genoende Nienke Weisglas-Kuperus (5) aangecoond 
dar blootstelling an verhoogde achrergrondconcentraties PCB's in kinde ren leidde cot een afgenomen respons op mazelenvaccinarie.

Daarbij moer worden opgemerkr dar een afgenomen waccinatierespons nier onmiddellipk behoeft te leiden tor afgenomen bescherming. De bandbreedte bij vaccinatie is groot, gelukkig mar. Een afgenomen vaccinatierespons geefr wel an dat er sprake is van een functioneel effect. Tegen lang net alle pathogenen wordr gevaccineerd, en het is voorstelban dat een afgenomen functionaliteit wan het immungysteen, aangetoond mer behulp van vaccinatieresponsen, repercussies heefr voor weerstand tegen pathogenen waartegen niet wordt gewaccinerd. Als voorbeeld weer de PCB's: door Nienke Weisglas werd niet alleen een afgenomen mazelenvaccinatie respons wargenomen geassocieed met blootstelling ath PCB's, ook werd een toename in de incidentie van middenooninfecties gezien.

In onderzoek nar de repercussies van blootstelling an immunotoxische pesticiden in de bevolking wordt, in international verband en in Maastricht samen met Gerard Swaen, Ludo van Amelswoort en Danielle Mohren, her model van vaccinatie roegepast.

We weten dat verschillende muizenstammen in verschillende mate gevoelig zijn voor de immunsuppressieve activireit van bijwoobeeld dioxine, een illustratie van de invloed van genetische achtergrond.

Bij de experimenten met UV uitgevoerd in de mens door Annematie Sleijfers was ook sprake van een genetisch effect. In een groep wan 200 vrijwilligers zag zij geen effect van ultraviolette straling op de vaccinatierespons tegen Hepatitis B. Zij zag dit pas, nadat zij de vrijwilligers opdeelde in verschillende groepen, gebaseerd op een bepaalde genetische achtergrond, in haar geval een polymorfisme voor het IL-1B gen. Met name in personen mer een bepalde verschijningsworm wan dar gen bleek dat effecten van UV heel duidelijk tot expressic kwamen. Dit geefran dat de ene mens de andere niet is (1.1).

Er zijn natuurlijk veel meer genen die van belang zullen zijn voor de immunologische reacties op toxische verbindingen. De ontsluting van het menselijke genoom, maar ook dat wan proefdieren, wal in de toekomst veel meer informatie gaan opleveren over mechanismen van toxiciteit, en dus ook wan immunotoxiciteic. Tevens zal deze informatic bijdragen aan het inzicht in het risicoprofiel dat personen met zich meedragen. 


\section{Vaststelleri yan ummunotoxiciteit: sensibilisatie}

Voor her wastrtellen van sensibiliserende eigenschappen wordt tegenwoordig heel wak de zogenamde "Local Lymph Node Assay", korweg LLMA, gebruke. In deze rest wordt de verbinding op her oor van cen muis angebracht, en wordt de immuunrespons als proliferatie van lymfocyten in de drainerende lymfklieren gemeten. Door het waststellen van dosis respons relaties kan een indruk worden gekregen wan her rellatieve sensibiliserende vermogen van de verbindingen. Deze test is verder ontwikkeld in die zin, dat niet alleen proliferatie kan worden gemeren, maar ook de interleukine respons in die lymfklieren in kart kan worden gebracht. Daze aanpak, waaran in her RIVM is gewerkr door Francois wan Och, Rob Vandebriel, en Wim de Jong, geeft informarie over de karakteristick wan de immuuncespons, met name de ecrder genoemde ThI/Th2 balans: hebben we te maken met een contact-sensitizer, zoals bijwoorbeeld DNCB, of juist met een respitatoir allergeen zoals TMA (12).

De LLNA word gehanteerd voor het vaststellen van sensibiliserende eigenschappen van stoffen, maar tegelijkerrijd is het natumlijk ook een functionele test van het immunnsysteem, die de extremen van de immunologische balans kan exploreren, door gebruik te maken exclusief Th1afhankelijke en exclusief Th2-ahankelijk antigenen zoals DNCB en TMA. Her ligt dan ook voor de hand om de functionele effecten van immunoroxiciteit van verbindingen te onderzoeken met deze test. Dit is een nicuwe aanpak, die elegant is door zijn eenvoud en door her integrale beeld dar wordr gemakt van effecten van stoffen op de balansen in het immuunsysteem. Preliminaire resultaten worden reeds geboekt in samenwerking me Harry van Steeg, in zijn onderzoek naar een mogelijk relatie wan carcinogenese met immunotoxiciteit. Her model zal ook worden toegepast in onderzoek naar mogelijke gunscige dan wel nadelige effecten van probiotica voor het immunnsysteem, gedeelrelijk uigevoend in samenweking met Ad Peijnenburg wan RIKILT in Wageningen.

\section{Nieuwe technologieën}

Een recente ontwikkeling op her gebied van het immunotoxicologisch onderzoek heb ik reeds whehtig angekondigd, toen ik sprak over genomgevingsinteracties. Het is zeer warschijnlijk dat veel effecten van toxi- 
sche verbindingen gepard zullen gatan met effecten op de expressie wa verschillende genen. Het ontsluiten van het genoom in mens en proefdiet heeft en enorme ortwikkeling doorgemaakt en zal in de toekomst een grote bijdrage leveren aan kennis over fysiologische en pathofysiologische processen.

Niauwe technologieèn, met name de nicroarray trechniek, warbij op kleine glaasjes honderden of zelfs duizenden genen kunnen worden gespot, en warmee verschillen in expressie na blootstelling an roxische verbindingen kunnen worden gedetecteerd, zal het inzich in gen omgevingsinteracties een nieuwe dimensie geven. De uitdaging ligt erin de enorme hoeveelheid gegevens, die dit type onderzoek zal opleveren, te interpreteren in termen van klinisch relevante gezondheidseffecten. Dir nieuwe vakgebied, ook wel roxicogenomics genoend, is een belangrijk aandachtspunt in het Maastrichrse, met name ook in de Capaciteitsgroep Gezondheid Risico Analyse en Toxicologie. De toepassing van deze technieken in de immunotoxicologie knjgt thans gestalte in een AlO project, dat wordt gesponsord door de Trans-Nationale Uniwersiteit Limburg, in de persoon van Kristen Baken, en onder begeleiding wan Joost wan Delft, Annemiek de Vries, Harry van Steeg, en Rob Vandebriel.

\section{Conclusie}

Concluderend wil ik her volgende zeggen. Bij gezondheid en ongezondheid is het immunsysteem van eminen belang. Meer dan de helft wan alle individuen in de bevolking lijdt jarlijks aan één of meerdere infecties, soms relatief onschuldig, soms zeker niet. Voorturend word: door her immunsysteem, als ware het cen zintuig, een surveillance uitgevoerd, en war nodig wordt een gerichte actie ondernomen. Hoewel een verstoring van balansen in het immunsysteem in leder individueel persoon nier onmiddellijk hoef te leiden tot ernstige consequenties, moen roch worden verwach dat een dergelijke verstoring in de bevolking wel een impact kan hebben op incidenties van infecties en tumoren. Een ldein immunotoxicologisch effect, dat op individueel nivo wellicht niet veel woorstelt, kan door de machr wan her getal op populatie nivo een behoorlijk effect hebben. Rekent u mat eens wit wat een griepperiode die gemiddeld een halwe dag extra duurt zou betekenen in termen van ziektever zuim. 
Verbindingen kunnen zelf allergie en autoimmunireir induceren, maar kunnen ook allergie of auroimmunite die zijn oorzak elders vinden beinvoeden. Dat in de bevolking een verstoring van de balans gaande likit wordt gellustreed door de toename in zowel allergische als autoimmumaandoeningen. Daar kome bij dat immunotoxische stoffen elkars effect mogelijk kunneri versterken.

Overigens is ook waar dat een effect van het ene agens heel goed een effect van een ander tenier kan doen. De lichte PCB belasting wa de moedermelk weegt nier op tegen de voordelen van borstvoeding. Een lichte verontreiniging van vis met $P C B$ s behoeft de positieve werking van visolievetzuren niet teniet te doen. Tenzij u zoveel vis eet dat u het optimum van de positieve effecten voorbij bent, en de schadelijke effecten van PCB's dominant kunnen worden. Een toestand die wellicht bij Eskimo kinderen in Noord-Canada word aangetroffen. Ook daar meer middenoorontstekingen als indicator woor gezondheidseffecten. In mijn optiek allemal voldoende redenen om tit onderzoek te stimuleren.

De enge manier om inzich in deze complexe materie te verkrijgen is her vergaten van kennis door middel wan multidisciplinair onderzoek: fundamenteel onderzoek naar mechanismen van gezondheidseffecten, toegepast onderzoek warbij dosis-effect relaries kunnen worden vastgesteld, onderzoek bij vrijwilligers, en epidemiologisch onderzoek. Voor de inmunotoxicologie ligt aansluiting bij ontwikkelingen op het gebied van chronische ontstekingen binnen het Maastrichts University Centre for Health (MUCH) voor de hand. In het kader van een bijzondere leerstoel, bezet geclurende een dag per week, is het een illusie te denken dat het gehele veld kan worden omsparnen. Door de inbedding van het onderzoek in Mastricht en in Bilthoven, alsmede in het nationale en internationale veld, zal toch een poging worden gedaan om ver te komen, met als specpunten de genoemde AlO projecten.

Uit her voorgande is $u$ wellicht opgevallen dat immunotoxicologie in het RIVM een veel langere tratitie kent dan in Mastricht, maar dat ik de rockomsrige on wikkelingen op dit gebied in Maastricht en Bilthoven tamelijk achreloos door ellkar heb behandeld. En zo wil ik het ook zien. Mijn streven is er op gericht de onrwikkeling van dit vakgebied wanuit beide instellingen gestalte te geven, witerard in beide instellingen vanuit hun eigen specifieke opriek, gericht op beleidsadvisering in her RIVM, en 
meer fundamenteel in de Universiteit, mat war mogelijk ellkar kruisbestuivend.

De enige manier waarop kennis op dit gebied kan worden doorgegewen en verder kan worden uitgebouwd, is dat $U$, dames en heren studenten, zich bij de keuze van uw studiepakket realiseert wat een belangwekkend, complex, maar daardoor ook spannend onderwerp immunotoxicologie is. Ik heb met vreugde nota genomen van de aandacht an de Immunologie binnen de Opleiding Moleculaire Levenswetenschappen wan de Transnationale Universireir Limburg, onder andere door Jeff Raus, terwijl ook in het curriculum van de Post-doctorale Opleiding Toxicologie, waaraan bijgedragen door de vrijwel de gehele Nederlandse toxicologische gemeenschap, een module Immunotoxicologie is opgenomen.

\section{Dankwoord}

Ik kom aan het einde van mijn rede, en wil deze besluiren met een dankwoord. In de eerste plaats dank ik de Universiteit van Maastricht, en met hat de Faculteit der Gezondheidswetenschappen voor de toestemming aan het RIVM verleend de bijzondere leerstoel Immunotoxicologie in te stellen, en het vertrouwen in mij om mij daarvoor voor te dragen. Ik dank het RIVM dat zij het van belang geacht heeft deze leerstoel te willen instellen en mij daarop te benoemen. Ik dank Jos Kleinjans van de Capaciteitsgroep Gezondheidsrisicoanalyse en Toxicologie, die met het RIVM in de personen van Gerrit de Mik en Sjef Vos de iniriële stappen heeft gezet om tor deze leerstoel te komen. Ik dank de Capacitcitsgroep GRAT, in de personen van Jos Kleinjans, Joost van Delft, Frederik-Jan Schooten, Marie-Claire van der Voort en andere collega's dat zij mij die ene dag per week zeer welwillend opnemen. Communicatie met andere collega's binnen het Maastrichtse is reeds aan het ontstaan, ik noem datrbij Gerard Swaen, Ludo van Amelsfoort, Danielle Mohren, Foekje Stelma, en JatiWillem Cohen-Tervater. Voor een deel in de Faculteit der Gezondheidswetenschappen en voor een deel in Geneeskunde: je zou kunnen zeggen dat wij al aan het vingeroefenen zijn voor het plan MUCH.

llk wil Sjef Vos danken voor het feit dat hij mij introduceerde in de immunotoxicologie, en mij gedurende de jaren dat wij samenwerkten heeft gestimuleerd, soms zelf opgejaagd, om te komen waar itk nu ben. De vele collega's in het RTVM, inmiddels voot een deel ook daar buiten, die 
ik niet alle met hame tal noemen om niet het gevar te lopen iemand te vergeten, dank ik voor hun soms jarenlange vruchbare samenwerking zonder welke nier rot stand zou zijn gebracht wat tot stand is gebracht. $\mathrm{K}$ wil Philp Askenase, van de Secrie Clinical Immunology and Allergy aan de Yale Unversity bedanken voor zinn inspanning mij te vormen op her gebied van de immunologie en het doen van wetenschap; een basis voor die vorming werd averigens gelegd door Willem den Otter, mijn promotor in Utrecht, warvoor ik hem dank.

1k dank mijn ouders voor hun seun vooral tijdens mijn studieperiode. Her is jmmer dat mijn vader fysick niet in stat is bij deze plechigheid alinwezig te zijn, en erger nog dat mijn moeder reeds is overleden, wardoor ze dit niet mer kan meemaken. Ze zou heel trors op me zijn geweest. Marar dan: ze was hoe dan ook heel trots op me, daar was ze mijn moeder voor".

Ik dank verder mijn gezin, mijn vrouw en mijn drie prachrige dochrers voor her bieden wan een thushaven van waruit her mogelijk is te doen war ik doe.

Ik dank u allen woor uw andache.

th beb gezegd. 


\section{Referenties}

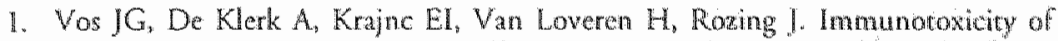

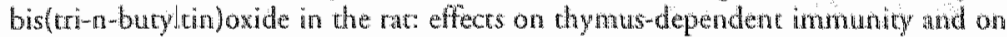
nonspecific resuscance following long-term exposure in young varsus aged rars. Toxicol Appl. Phamacol. 1990, 105, 144-155.

2. De Waal EJ, Schumrman HJ Van Loveren H. Vos JG. Differential effects of 2,3,7,8-terachlorodibenzo-p-doxin, bis(ri-n-bucyluntoxide and cyclosporine on thymus histophysiology. Crit.Rev. Toxicol. 1997,27,381-430.

3. R.L. de Swarm, P.S. Ross, E. J. Vedder, H. Timmerman, S.H. Heisterkamp, H. van Loveren, J.G. Vos, P.J.H. Reijnders, A.D.M.E. Osterhaus. Impairment of immunological functions of harbour seals (Phoca vitulina) feeding on fish from polluted coastal waters. AMBIO 1994, 2, 155-159.

4. Ross PS, De Swart RL, Van der Vlier H, Willemsen L, De Klerk A, Van Ameron. gen G, Groen I, Brouwer A, Schipholt I. Morse DC, Van Loveren IH, Ostathas ADME Vos JG. Impared cellular immune exponse in tars exposed perinatally to Balcic Sea herring oil or $2,3,7,8$ TCDD. Archives of Toxicology 1997, 17, 563 . 574 .

5. Weisglas-Kuperus, N. Paradin, S., Berbers, GA, Sats, TC, Saver PJ, Hooifkass H. Immunologic effects of background exposure to polychlorinated biphenyls and dioxins in Durch preschool children. Enwiron Health Perspect. 2000, 108, 12031207.

6. Garssen J, Van Loveren H. Efects of tultraviolet exposure on the immune system. Critical Reviews in Immunology, $2001,21,359-397$.

7. Termorshuzen F, Wijga $A$, Gerritsen J, Nijens $H$, Van Loveren H. Exposure to uluaviolet radiatoion and respiratory tract symptons in 1 year old children. Submitred for publication.

8. Steenenberg [A, Dormans JAMA, Van Doorn GCM, Middendorp S, Vos JG, $V_{\text {an }}$ Loveren $H$. A pollen model in the rat for cesting adjuvant activity of air polIution components. Thatation Toxicology 1999, 11, 1. 109 1122.

9. Van Ziverden M, De Har C, Beelen $A$, Van Loveren H, Penninks $A$, Peters $R$. Coadministration of antigen and particles optimally scimulates the immune response in an incranasal administration model in mice. Toxicology and Applied Phanacology, $2001,177,174-178$.

10. Midnelsen CPPC, Van Loveren $\mathrm{H}$, Vos JG. The role of the immune system in hexachlorobanzene-induced toxicity. Environnental Healh Perspectives 1990, 107 (Suppl. 5). 783792 .

11. Sleiffer: A. Yucesoy B, Kashon M. Garsen J, De Gruil PR, Boland GI, Van Hatcum J, Luster $\mathrm{MI}_{\mathrm{i}}$ Van Loveren H. Cytokine polynorphisms play a role in susceptibiliry to ulkraviolet. B-induced modulation of immune responses after hepatitis B vaccination. J Immunol 2003, $170,3423-3428$

12. Van Och FMM, Van Loveren H, De Jong WH, Vandebriel B. Cytokne producion indeced by low-molecular-weight chemicals as a funcrion of the stmula tion index in a modified local lymph node assay: an approach ro discriminate contact sensitizers from respirarory sensitizers. "Toxicology and Applied Pharmacology $2002,184,46-56$ 